The effect of music and summarizing of the short stories on

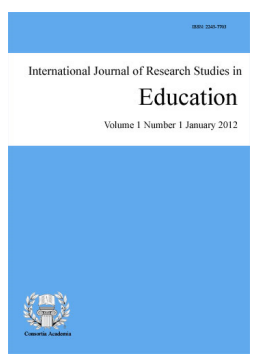

Sadrameli, Mohammad Hassan $\$
Department of English, Isfahan (Khorasgan) Branch, Islamic Azad University, Isfahan, Iran (m_sadrameli@yahoo.com)

\title{
Abstract
}

This study attempted to compare the effects of teaching English speaking through song and short story on learners' knowledge of oral proficiency. Through an OPT test, 60 students out of 100 were chosen and randomly divided into two experimental and one control group each consisting of 20 students. The two experimental groups were instructed to apply song and short story on the same topics except the control group which received traditional methods of teaching speaking. The mean scores of both experimental and that of control groups were compared through One-way Analysis of Variance (ANOVA). The results of analysis showed that the groups who utilized short story and song outperformed the control group in speaking skill. Furthermore, the experimental group who received short story treatment, revealed a significant efficiency more than song group. As a result, it can be concluded that short story group outperformed the song group and song outperformed the control group in immediate posttest.

Keywords: music; short story; speaking skill; traditional methods; EFL learners 


\section{The effect of music and summarizing of the short stories on English language learners' speaking skill}

\section{Introduction}

Speaking is a very crucial part of English language teaching and learning. Globalization, creates a necessity to communicate English effectively in all aspects of the life. People usually assume that the ability to speak is the product of language learning (Aye \& Phyu, 2015). Speaking is the basic skill, undoubtedly important in a second language acquisition process:

Speaking is one of the most difficult skills language learners have to face. In spite of this, it has traditionally been forced into the background while we, teachers of English, have spent all our classroom time trying to teach our students how to write, to read and sometimes even to listen in a L2 because grammar has a long written tradition (Bueno, Madrid, \& Mclaren, 2006, p. 231).

Shumin, (2002) discussed that speaking a language involves more than knowing the linguistic components of the message and developing language skills; therefore, it needs more than grammatical comprehension and vocabulary memorization. Chastain, (1988) stated that like any language skill, foreign language learners need explicit instructions in speaking. Language students need to learn to speak the language in order to communicate with each other. Speaking supplies a change of pace in the classroom routine. Speaking is the natural state of language, as all human beings are born to speak their native languages. It is thus the most distinguishing feature of human beings. This verbal communication involves not only producing meaningful utterances but also receiving others' oral productions. Speaking is thus regarded as a critical skill in learning a second or foreign language by most language learners, and their success in learning a language is measured in terms of their accomplishment in oral communication (Nunan, 1998; Nunan, 2001).

The use of music and song in the English language-learning classroom is not new. As early as Bartle (1962), Richards (1969) and Jolly (1975), scholars have been arguing for use of music in a language acquisition context for both its linguistic benefits and for the motivational interest it generates in language learners. Music had been used on occasion with the Audiolingual Method in language teaching classrooms to reduce the boredom that could occur from repetitive drills from the 1950s through to the 1970s (Bartle, 1962; Kanel, 2000) and later, the use of classical instrumental music was used with the goal to produce a relaxed state of mind that makes the brain receptive to inputs and activates the subconscious in Suggestopedia methodology (Lozanov, 1978; see also Bancroft, 1978). In addition to music, short stories are also useful in speaking. They allow instructors to teach the four skills to all levels of language proficiency. Murdoch, (2002) indicates that "short stories can, if selected and exploited appropriately, provide quality text content which will greatly enhance ELT courses for learners at intermediate levels of proficiency" (p. 9).

As the importance of speaking mentioned above, the need for new strategies of teaching speaking is necessary. Most of the Iranian learners complain about teaching speaking they spend a lot of time in institutes and schools but they cannot speak English. Although, a lot of studies have been done on the speaking already but nobody has studied the effect of using song and short stories on teaching speaking together. So, the purpose of this study is to investigate the effect of using song and short stories on speaking skill.

Speaking is an interactive process of building meaning that includes producing and receiving and processing information. Its form and meaning depends on the context in which it happens, including the participants themselves, their collective experience, the physical environment, and propose for speaking. It is usually spontaneous, open-ended and evolving (Florez \& Cunningham, 1999). According to Rizvi (2009) speaking is an interactive communicative process that includes speakers and listeners. In communicative process, speakers need 
The effect of music and summarizing of the short stories on English language learners' speaking skill

to learn to adapt their talk to the listeners; use a range of ways to express themselves; use to clarify their ideas and keep their talk to develop reasoning and thinking. Speaking is not oral production of written language, but includes learners in the dominancy of a lot of sub-skills, which added together, constitute an overall competence in the spoken language (McDonough \& Shaw, 2003).

In our lives, we use talk in different ways for different purpose and audiences. As a skill that enables us to produce utterances, when genuinely communicative, speaking is desire and purpose-driven, in other words we genuinely want to communicate something to achieve a special purpose. This may involve expressing ideas and opinions, expressing a wish or desire to do something, negotiating or solving a particular problem, or establishing and maintaining social relations and friendships (Burnett \& Myers, 2004).

\section{Literature Review}

Many language learners learning a second language regard to speaking ability as the measure of knowing that language. These learners define fluency and accuracy as the ability to converse with others, much more than ability to read, write, or comprehend oral language. They consider speaking as the most important skill they can acquire, and they asses their progress in terms of their accomplishments in spoken communication. The speaking ability in a second language can more or less be divided into two categories: accuracy and fluency (Hue, 2008). a.) Accuracy centers on correct use of grammar, vocabulary and other skills. In most lessons, the teacher builds accuracy in the early stages through controlled or semi-controlled activities. Students practice a pattern, and use the language in the context. Drills, scripted dialogues and short questions which promote the language in any level of lesson. b.) Fluency is the ability to speak smoothly and clearly. With advanced students, it also refers to the ability to participate rather than react to a conversation. Activities which focuses on fluency often appears towards the end of lesson, when open-ended activities appear.

Speaking competence has a significant role in learning and understanding any language. The term of speaking has different meanings. Widdowson (1978) says that speaking has two meanings. First, it refers to the manner in which language is manifested. Second, it refers to the manner in which language is realized as communication .

According to Chomsky (as cited in Brumfit \& Johnson, 1998) the meaning of competence is the speaker hearer's knowledge of his language. It is considered as overall underlying linguistic knowledge and ability thus includes concepts of appropriateness and acceptability. While in Curriculum 2004 competence is defined as knowledge, skill, behavior, and values which accustom to be applied in the habitual thought and action. Then according to Oxford Advance Dictionary by Hornby, competence is (of person) having ability, power, authority, skill, knowledge, etc. (to do what is needed). The goal of language teaching is that the students become communicatively competence in target language as capability of using language well. Richard and Roger, (1999) state that Communicative Language Teaching (CLT) is an approach that aims to create communicative competence and develop procedure for the teaching of the four language skills (listening, speaking, reading and writing) that acknowledge the interdependence of language and communicative activities.

Different scholars have emphasized and certified the benefits of using short stories and song in teaching English in general and speaking in particular. Regarding to the use of short stories in the language classes Khatib and Nasrollahi, (2012, pp. 240-246) "believe that short story like other literary texts can raise cultural awareness, linguistic awareness, motivation, and many others". Short stories is claimed to improve all four skills. According to Erkaya (2005 as cited in Ebrahiminejad, Azizifar, Gowhary, \& Jamalinesari, 2014) researchers who advocate the use of short stories to teach ESL/EFL list several benefits of short stories such as: motivational, literary, cultural and higher-order thinking benefits. Lo and Li (1998 as cited in Ghanbari \& Hashemian, 2014) mention that songs play a significant role in motivating the L2 learners to learn English. They can support the progression of L2 learners' skills in reading, writing, listening and speaking, as well as provide opportunities for learning pronunciation, rhythm, grammar and vocabulary. Besides, songs often offer variety and change from routine, 
Sadrameli, M. H.

repetitive classroom activities to a fun and lively atmosphere in class, as Schoepp (2001) exhibits that songs can create a relaxing, entertaining and non-threatening classroom atmosphere and L2 learners will be more open to learning in this regard. Following are some of the most recent studies on using short story and song in teaching English.

In a recent study Aye and Phyu (2015) tried to determine the effects of the use of English short stories as an authentic material for developing speaking skill. The research intends to provide some practical use of short stories to create lively and communicative lessons with the occasional provision of forms and functions. Drawing upon the findings and results of the students' performance, the study showed that short stories help to improve students' spoken fluency and the cultivation of interest in literature. Ebrahiminejad et al. (2014) investigated the effects of using short stories on English as a foreign language (EFL) learners' speaking skill. Data from this study demonstrate a significant role for using simplified short stories in improving the speaking skills of participants in the experimental group.

In addition, Kayi (2006 as cited in Ebrahiminejad et al, 2014) demonstrated that storytelling improves speaking. Students can briefly summarize a tale or story they heard from someone beforehand, or they may create the story of their own life to tell their classmates. According to Khosravani and Ganji Khoosf (2014), the technique of reading simplified short stories can improve the learners' speaking skill. The results of their study also proved that being exposed to suitable literary texts has significant effect on EFL learners' listening skill. All of the above studies certified the effectiveness of using short sorties in learning English and speaking skill. Related to using song Ghanbari and Hashemian, (2014) investigated the effect of using songs on young L2 learners' listening comprehension and pronunciation. The results revealed that utilizing songs in L2 classes had a positive effect on the L2 learners' listening comprehension and pronunciation skills. Moradi and Shahrokhi, (2014) also investigated effectiveness of using music on segmental and suprasegmental pronunciation. The results of comparing the pretest and the posttest showed that music had a better effect on pronunciation and intonation and stress pattern recognition; that is, the students in the experimental group had a better performance in these areas than the control group. Although, mentioned studies certified the effectiveness of using song but there was not any study regarding effect of song on speaking.

The present study aimed to address the following question:

$>\quad$ To what extent does using short story, song and traditional approaches affect students' speaking skill?

\section{Methodology}

\subsection{Participants}

The participants of this study were 60 intermediate male learners within the age range of $17-21$. Their native language was Persian. Before commencing the experiment, the experimental group's participants, and their parents was made aware of the study so as to minimize any misunderstanding pertained to the study throughout the research. This was in line with the ethical issues. In order to increase validity and avoid any cultural and social differences all of the participants were chosen from the same institute.

\subsection{Instrumentation}

The first instrument of the study was an OPT test. It was used to determine the participants' level of language proficiency to make sure that the chosen participants had the same level of language proficiency. The other instrumentations in this study included a speaking pre-test that was conducted before the treatment. Finally, a post-test was given to experimental and control group at the end of the semester in order to compare the performance of the two groups and measure the effectiveness of using short story and song on experimental groups. 


\subsection{Data Collection Procedures and analysis}

Through an OPT test among 100 students 60 students were selected and randomly divided into two of groups experimental and one control group. After the pretest, students randomly divided into two experimental groups and one control group the first group of students (first experimental group) comprising 20 participants were chosen to see the influence of short story on speaking skill. The second group of students (second experimental group) comprising 20 participants was chosen to see the influence of song on speaking skill. The third group of students (control group) consisting of 20 participants were selected randomly in order to investigate the effects of traditional teaching methods on speaking skill.

In the all groups, a speaking test was adopted as a pre-test. The students in all groups were asked to answer the questions in this test. After this stage, the students in the traditional class (control group) were taught speaking through traditional approaches, short story was used to first experimental group and using song was used in teaching second experimental group. At the end of the term, the students were required to take a posttest which assessed their speaking knowledge. One way ANOVA was employed to see if there were significant differences in speaking between the control and experimental groups.

\section{Results}

\subsection{Results of the pre-test stage}

To answer the research question of the study, addressing the effectiveness of short story and song on participants' speaking skill, a set of ANOVA was run between the participants' scores of the experimental and control group on pretest and posttests. The descriptive statistics of pre-test are presented in Table 1.

\section{Table 1}

Descriptive Statistics of the Participants' Performance on the Speaking Pretest

\begin{tabular}{lcccccc}
\hline & $n$ & Mean & SD & SE & Min. & Max. \\
\hline short story group & 20 & 27.40 & 3.78 & .84 & 21 & 33 \\
song group & 20 & 28.00 & 1.89 & .42 & 23 & 31 \\
control group & 20 & 26.90 & 3.23 & .72 & 23 & 33 \\
$\quad$ Total & 60 & 27.43 & 3.05 & .39 & 21 & 33 \\
\hline
\end{tabular}

According to the above table, the mean of the song group was higher than the other two groups and the standard deviation of two groups were also different. After collecting the data, ANOVA was performed using SPSS to see whether the differences between the three groups' were significant or not. The results are presented in Table 2.

\section{Table 2}

One-way ANOVA for comparing the performance of groups (pre-test)

\begin{tabular}{ccccccc}
\hline & $\begin{array}{c}\text { Sum of } \\
\text { Squares }\end{array}$ & df & $\begin{array}{c}\text { Mean } \\
\text { Square }\end{array}$ & F & Sig. & $\begin{array}{c}\text { Partial Eta } \\
\text { Squared }\end{array}$ \\
\hline Between Groups & 12.13 & 2 & 6.067 & .644 & .529 & .02 \\
Within Groups & 536.60 & 57 & 9.414 & & & .02 \\
Total & 548.73 & 59 & & & & \\
\hline
\end{tabular}

According to Table 2, the mean differences between the three groups was not significant $(p=.529)$. This shows that the students in the three groups were at the same level of speaking knowledge.

\subsection{Results of the post-test stage}

The same statistical procedure was used for the posttest results. The statistical analysis of the posttest for the 
Sadrameli, M. H.

experimental and the control group is presented in Table 3.

Table 3

Descriptive Statistics for the Participants' Performance on the Speaking Posttest

\begin{tabular}{lcccccc}
\hline & $n$ & Mean & $S D$ & $S E$ & Min. & Max. \\
\hline short story group & 20 & 35.75 & 1.86 & .42 & 33 & 40 \\
song group & 20 & 32.55 & 1.61 & .36 & 30 & 36 \\
control group & 20 & 28.15 & 3.47 & .78 & 24 & 36 \\
& 60 & 32.15 & 3.96 & .51 & 24 & 40 \\
\hline
\end{tabular}

The mean score of the first experimental group (short story group) which received short story as the treatment, was raised from 27.40 on the pre-test to 35.75 on the post-test, which showed an improvement in speaking knowledge. The mean score of the second experimental group,(song group) which used song as the treatment, was increased from 38.000 on the pre-test to 32.55 on the post-test which indicated an improvement less than what we observed in the first experimental group. The control group's mean score was improved from 26.90 to 28.15 showing a little improvement. In order to find out whether there are statistically significant differences in the effects of short story and song on the learners' performance in three groups, the post-test scores were submitted to a one-way ANOVA analysis with between-group factor that are shown in the following table.

Table 4

One-way ANOVA for comparing the performance of groups (post-test)

\begin{tabular}{ccccccc}
\hline & $\begin{array}{c}\text { Sum of } \\
\text { Squares }\end{array}$ & df & $\begin{array}{c}\text { Mean } \\
\text { Square }\end{array}$ & F & Sig. & $\begin{array}{c}\text { Partial Eta } \\
\text { Squared }\end{array}$ \\
\hline Between Groups & 582.400 & 2 & 291.200 & 48.357 & .000 & .62 \\
Within Groups & 343.250 & 57 & 6.022 & & & .62 \\
Total & 925.650 & 59 & & & & \\
\hline
\end{tabular}

As table 4 show, the results $(p=.000)$ illustrated that the difference between the performance of three groups is statistically significant. In other words, short story and song had a supportive role on speaking proficiency.

\section{Discussions}

In this study, the researcher compares the two strategies of teaching speaking. The research questions addressed in this study intended to investigate the role short story and song in learning speaking. This research was designed to answer to the following question:

$>\quad$ To what extent does using short story, song and traditional approaches affect students' peaking skill?

The researcher has shown that the instruction through the short story and song for teaching speaking had an advantage over the traditional method, since the students in the two experimental groups outperformed that participant in the control group. These findings also showed that the short story group seemed to have higher scores in posttest compared to song and traditional group. After analyzing the data through descriptive statistics and applying one way ANOVA on the experimental and control groups' performance, the results revealed that the two experimental groups outperformed the control group in speaking skill. Therefore, it can be said that the training program based on the short story and song could have positive effects on the experimental groups' performance on the speaking. The results of the study are in line with the following studies:

Ebrahiminejad et al. (2014) certified the effectiveness of using short stories on English as a foreign language (EFL) learners' speaking skill. He showed that using simplified short stories improved participants' speaking skill. Khosravani and Ganji Khoosf (2014) also, showed that using short stories technique can improve the learners' speaking skill and listening. In a recent study Aye and Phyu (2015) indicated that short stories help to improve students' spoken fluency and the cultivation of interest in literature. All of the above studies support our 
The effect of music and summarizing of the short stories on English language learners' speaking skill

findings. Although, there was not any study about the effectiveness of using song in teaching speaking but Ghanbari and Hashemian, (2014) indicated that using songs affect students' listening and pronunciation positively. Moradi and Shahrokhi (2014) also studied the effect of using music on segmental and suprasegmental pronunciation. The results showed that music had a significant effect on pronunciation and intonation and stress pattern.

\section{Conclusion}

The present study was designed to determine the effect of short story and song on the development of speaking skill among intermediate Iranian students. The results of the study showed that using both short story and song in teaching speaking can improve students' knowledge of speaking. This study has shown that the application of short story and song in EFL context can improve intermediate learners' knowledge of oral proficiency. In addition, learners find these strategies enjoyable and helpful in teaching speaking. In general, it was clear that both short story and song was effective in speaking proficiency but short story seemed more effective than song. As everyone knows, speaking is the main feature of learning language. Because access to native language is not possible so we need different activities to improve our speaking knowledge. After conducting this study, we concluded that using short stories and songs are two useful strategies for developing our speaking knowledge.

\section{References}

A. Bueno, D. Madrid, \& N. McLaren (Eds). (2006) TEFL in secondary education (pp. 129-133). Granada: Editorial Universidad de Granada.

Aye, K. K., \& Phyu, K. L. (2015). Developing students' speaking skill through short stories. Yangon University of Education Research Journal, 5(1), 1-11.

Bartle, G. (1962). Music in the language classroom. Canadian Modern Language Review, Fall, 11-14.

Brumfit, C. J., \& Johnson, K. (1998). The communicative approach to language teaching. Oxford University Press.

Burnett, C., \& Myers, J. (2004). Teaching English 3-11: The essential guide for teachers. A\&C Black.

Chastain, K. (1988). Developing second-language skills: Theory and practice (3rd ed., pp. 138-164). San Diego: Harcourt Brace Jovanovich, Inc.

Ebrahiminejad, S., Azizifar, A., Gowhary, H., \& Jamalinesari, A. (2014). Effect of using short story on speaking improvement of Iranian pre-intermediate TEFL learners. International Journal of Language Learning and Applied Linguistics World, 7(3), 42-56.

Erkaya ,R. O. (2005). Benefits of using short stories in the EFL context .Asian EFL Journal, 8, 49-38.

Florez, M. A. C. (1999). Improving adult English learners' speaking skills. Washington, DC: National Clearing House for ESL literacy Education.

Ghanbari, F., \& Hashemian, M. (2014). The effects of English songs on young learners' listening comprehension and pronunciation. International Journal of Language Learning and Applied Linguistics World, 6(3), 337-345.

Hue, C. (2008). Teacher talk time/student talk time (unpublished Dissertation). Austral de Chile university.

Jolly, Y. S. (1975). The use of songs in teaching foreign languages. The Modern Language Journal, 59(1-2), 11-14. https://doi.org/10.1111/j.1540-4781.1975.tb03618.x

Kanel, K. (2000). Songs in language teaching: Theory and practice. In Proceedings of the JALT (Japan Association for language Teaching) 25th Annual international conference on language teaching \& learning and educational materials expo (pp. 69-75). Canadian Center of Science and Education.

Kayi, H. (2006). Teaching speaking: activities to promote speaking in a second language. The Internet TESL Journal. Retrieved from http://unr.edu/homepage/hayriyek

Khatib, M., \& Nasrollahi, A. (2012). Enhancing reading comprehension through short stories in Iranian EFL learners. Theory and Practice in Language Studies, 2(2), 240-246. 
https://doi.org/10.4304/tpls.2.2.240-246

Lo, R., \& Li, H. C. (1998). Songs enhance learner involvement. English Teaching Forum, 36(2), 8-11.

Lozanov, G. (1978). Suggestology and outlines of suggestopedy. New York: Gordon and Breach Publishing. https://doi.org/10.4324/9780203392829

McDonough, J., \& Shaw, C. (2003) Materials and Methods in ELT: A teacher's guide. John Wiley \& Son..

Moradi, F., \& Shahrokhi, M. (2014). The effect of listening to music on Iranian children's segmental and suprasegmental pronunciation. English Language Teaching, 7(6), 128-142. https://doi.org/10.5539/elt.v7n6p128

Murdoch, G. (2002). Exploiting well-known short stories for language skills development. IATEFL LCS SIG Newsletter 23, 9-17.

Nunan, D. (1998). Language teaching and methodology. London: Prentice Hall.

Nunan,D. (2001). Aspect of task-based syllabus design. Retrieved from http://www3.telus.net/linguisticsissues/syllabusdesign.html

Richards, J. (1969). Songs in Language Learning. TESOL Quarterly, 3(2), 161-174. http://dx.doi.org/10.2307/3586103

Richards, J. C., \& Rodgers, T. S. (1990). Approaches and methods in language teaching. A description and analysis. Cambridge University

Rizvi, M. A. (2005). Effective technical communication. Tata McGraw-Hill publishing company limited.

Schoepp, K. (2001). Reasons for using songs in the ESL/EFL classroom. The Internet TESL Journal, 7(2), 54-68.

Shumin, K. (2002). Factors to consider: Developing adult EFL students' speaking abilities. Methodology in language teaching: An anthology of current practice, 12, 204-211. https://doi.org/10.1017/CBO9780511667190.028

Widdowson, H. G. (1978). Teaching language as communication, Oxford University Pres 